\title{
Single cell protein as an occupational hazard
}

\author{
LENA EKENVALL, ${ }^{1}$ BARBRO DÖLLING, ${ }^{1}$ C-J GÖTHE, ${ }^{1}$ L EBBINGHAUS, ${ }^{2}$ L-V VON \\ STEDINGK,${ }^{3}$ AND J WASSERMAN ${ }^{3}$
}

From the Department of Occupational Medicine, ${ }^{1}$ Södersjukhuset, Stockholm, Norprotein, ${ }^{2}$ Sundbyberg, and Department of Bacteriology, ${ }^{3}$ Central Microbiological Laboratory of Stockholm County Council, Stockholm, Sweden

ABSTRACT Single cell protein (SCP) intended for animal feed purposes was produced in a pilot plant. The SCP consisted of Methylomonas methanolica, a pseudomonas species which is an obligate methanol user. The SCP was cultured in fermenters and later dewatered and dried in a spray-drier. Seven of eight research workers had febrile reactions 6-12 hours after exposure to SCP dust. All workers had high titres of IgG and IgM antibodies against the pseudomonas species as measured with indirect ELISA and passive haemagglutination techniques. The mechanism behind the febrile reaction is judged to be a non-immunological reaction caused by endotoxins. By increasing the particle size of the SCP through using different drying procedures, a product which generated less dust was obtained.

Different means by which to guarantee the global supply and distribution of available sources of proteins were discussed in the 1960 s. $^{1}$ At that time there were doubts of the ability of agriculture and the fishing industry to supply the increasing need for protein feed supplements. An exploitation of microorganisms was considered as one possibility to cover the protein shortage. ${ }^{2}$ Many microorganisms have a high protein content and may be produced in large quantities by industrial fermentation from simple raw materials with a low or no nutritional value. A new technology was developed that exploited fungi, yeasts, and bacteria to produce so-called single cell protein (SCP) with a high nutritional value from inorganic nutrients and simple organic chemicals, such as hydrocarbons, alcohols, or carbohydrates. ${ }^{34}$ During the past 20 years several SCP processes have been developed, and in the 1970 s pilot and full-scale plants were built. ${ }^{56}$

We describe an occupational hazard associated with the production of SCP intended for animal feed purposes and discuss some aspects on solving the problem of SCP inhalation.

\section{Production procedure and description of the disease}

An obligate methylotrophic bacterium, a pseudomonas species (Methylomonas methanolica), was used as the production strain. ${ }^{78}$ In a pilot plant

Received 15 February 1982

Accepted 7 May 1982 the organism was cultured under aerobic conditions in a substrate containing methanol and nutrient salts. After fermentation the culture was initially concentrated in a continuously operating separator. Later, a more efficient dewatering method was developed, using a flocculation/flotation procedure. Finally, the product was dried in a conventional spray drier with a rotating atomiser and then bagged.9 Atomisation of the wet material by the rotating sprayer produced a very dusty product, especially when, initially, the cells were not flocculated before drying. Later still, the conventional spray drier with the rotating atomiser was exchanged, and a drying tower with stationary nozzles was tested for drying the flocculated suspension.

The microorganism, being methanol dependent, is not considered pathogenic to man and no personal safety equipment was initially used by the workers.

Eight people were engaged in the pilot plant. A short time after the start-up of the spray-drying and bagging procedures, the first symptoms occurred in the exposed group, and during the following months seven of the workers fell ill on one or more occasions. Six to twelve hours after exposure to SCP dust they had attacks of an influenza-like illness with shivering, fever, tightness of the chest, and, in some cases, dry coughing and muscle pains. Usually the complaints started in the evening after exposure and disappeared by the next morning. Five of the workers also had acute symptoms of conjunctivitis, rhinitis, or coughing immediately after contact with 
SCP dust. Two others, not engaged in the production and not included in this study (the wife of one of the workers and the hygienist doing the dust measurements) experienced symptoms at their first known exposure to the SCP dust. Obligatory use of respirators in the spray-drier and silo rooms prevented all symptoms except conjunctivitis, since the respirators did not protect the eyes.

\section{Subjects and methods}

The health problems among the workers were observed during the initial stage of the development, before the dewatering methods were changed, and at this stage the level of air-borne dust was measured in the plant by stationary pumps placed at the work sites and mobile pumps worn by the workers. The pumps were connected to Millipore filters on which the dust was collected. The stationary equipment was placed close to the working zones, and the filters of the mobile equipment were placed on the shoulder, $10-15 \mathrm{~cm}$ from the nose of the worker. The filters were weighed after drying before and after the dust collection.

The particle size distribution of the dried product was measured on a Retsch sieve DIN 1171 before and after the change of the dewatering technique.

For the preparation of antigen, fresh cells of Methylomonas methanolica were suspended in distilled water and disintegrated by stirring for 15 minutes at $5000 \mathrm{rpm}$ in the presence of $0.5 \mathrm{~mm}$ glass beads. The supernatant obtained after centrifugation for 20 minutes at $6000 \mathrm{~g}$ was used as the antigen in the immunological tests.

Class specific circulating antibodies against the antigen were determined by an indirect ELISA technique. ${ }^{10}$ The test was performed essentially as described by Wasserman et al. ${ }^{11}$ Polystyrene microtitre plates were coated with the antigen by incubation at a concentration of $20 \mu \mathrm{g}$ protein $/ \mathrm{ml}$ in a $0.05 \mathrm{M}$ sodium carbonate buffer, $\mathrm{pH} 9.6$ for a minimum of 24 hours at $4^{\circ} \mathrm{C}$. After washing the plates, serum samples diluied in the ratio of $1: 1000$ for IgM and 1:10 000 for IgG determination were added to the wells. The plates were incubated for 90 minutes at $37^{\circ} \mathrm{C}$ and then washed. Alkaline phosphatase conjugated to antihuman IgG or IgM was added, and the plates were incubated at room temperature overnight. After washing, pnitrophenyl-phosphate was added. The reaction was stopped after one hour, and the absorbance was measured at $405 \mathrm{~nm}$. The ELISA values are expressed as absorbance at $405 \mathrm{~nm} \times 1000$ as measured by a Multiscan plate reader (Flow Laboratories, Stockholm).

The presence of antibodies against the organism used for the production of SCP was also determined by the passive haemagglutination technique. ${ }^{12}$ The concentration of the antigen used for coating the cells was $100 \mu \mathrm{g} / \mathrm{ml}$. Two-fold dilution was used and the haemagglutination titres were expressed as reciprocals of the dilutions.

\section{Results}

\section{DUST MEASUREMENTS}

As shown in table 1, the dust levels were low when the process was not running. The main part of the dust emerging from the process presumably consisted of SCP. When the fermentation and drying processes were running, the dust level in the process hall was still low. In the spray drier and the silo rooms, however, the dust levels were considerably higher, especially when the product was packed into bags.

Table 2 shows particle size distribution of the product before and after the change of the dewatering technique. Initially, a significant fraction of the air-borne SCP dust was respirable. The particle size increased as soon as the flocculation/flotation procedure was introduced, and when the drying tower with stationary nozzles was used the size was further increased.

\section{MEDICAL EXAMINATION}

Only one person had a history of earlier allergic disease (allergic rhinitis). All those examined were asymptomatic at the time of examination. Pulmonary radiographs were normal throughout.

Table 1 Air-borne dust levels at different work sites and activities

\begin{tabular}{|c|c|c|c|c|}
\hline Work site & Activity & $\begin{array}{l}\text { Time for dust } \\
\text { collection (min) }\end{array}$ & $\begin{array}{l}\text { Time-weighted average } \\
\text { of airborne dust } \\
\left(\mathrm{mg} / \mathrm{m}^{3}\right)\end{array}$ & Dust collector \\
\hline Process hall & $\begin{array}{l}\text { Process surveyance } \\
\text { Process-off } \\
\text { Starting-up }\end{array}$ & $\begin{array}{r}420 \\
66 \\
212\end{array}$ & $\begin{array}{r}<0 \cdot 2 \\
<0 \cdot 2 \\
1 \cdot 4\end{array}$ & $\begin{array}{l}\text { Mobile } \\
\text { Stationary } \\
\text { Stationary }\end{array}$ \\
\hline Spray drier & $\begin{array}{l}\text { Starting-up } \\
\text { Process-operation } \\
\text { No process going }\end{array}$ & $\begin{array}{l}222 \\
290 \\
440\end{array}$ & $\begin{array}{l}4 \cdot 0 \\
4 \cdot 0 \\
0 \cdot 2\end{array}$ & $\begin{array}{l}\text { Mobile } \\
\text { Stationary } \\
\text { Stationary }\end{array}$ \\
\hline Silo & $\begin{array}{l}\text { Sack-filling } \\
\text { Sack-filling }\end{array}$ & $\begin{array}{l}27 \\
62\end{array}$ & $\begin{array}{l}19 \cdot 3 \\
22 \cdot 3\end{array}$ & $\begin{array}{l}\text { Stationary } \\
\text { Mobile }\end{array}$ \\
\hline
\end{tabular}


Table 2 Particle size distribution of spray dried cell concentrates (sieve analysis), for cell suspensions treated with different methods according to text

\begin{tabular}{|c|c|c|c|}
\hline $\begin{array}{l}\text { Particle size } \\
\text { distribution, } \\
\text { weight } \% \\
\text { um }\end{array}$ & Sample 1 & Sample 2 & Sample 3 \\
\hline$<10$ & 30 & 3 & 0 \\
\hline $10-19$ & 38 & 13 & 0 \\
\hline $20-39$ & 30 & 57 & 0 \\
\hline $40-59$ & 2 & 21 & 0 \\
\hline $60-89$ & & 6 & 0 \\
\hline 90-119 & & & 2 \\
\hline $120-179$ & & & 11 \\
\hline $180-249$ & & & 45 \\
\hline $\begin{array}{c}250-349 \\
\geqslant 350\end{array}$ & & & $\begin{array}{l}19 \\
23\end{array}$ \\
\hline Pretreatment & None & Flocc/flot & Floce/flot \\
\hline $\begin{array}{l}\text { \% Evaporable } \\
\text { material before }\end{array}$ & & & \\
\hline drying & 95 & 80 & 80 \\
\hline Type of spray & Rotating & Rotating & Stationary \\
\hline drier & atomiser & atomiser & nozzles \\
\hline
\end{tabular}

Floc/flot $=$ Flocculation/flotation.

Spirometry and exercise testing on an ergometer cycle, combined with arterial blood gas analysis at rest and work, gave normal results in all examined cases, as did the routine blood tests, including ESR, $\mathrm{Hb}$, and leucocyte differential count. All those examined had normal levels of total IgE-antibodies and normal eosinophil leucocyte counts.

As shown by the ELISA technique, all those exposed to the dust had serum antibodies against the water soluble extract of the SCP (table 3 ). In four cases there was an increase of IgM, and in five cases of IgG antibodies from the first specimen to the second taken about two to three months later. Thus the relative ELISA value for IgM or IgG of at least one serum specimen was higher than those of unexposed controls (healthy blood donors) (table 4). Six patients had also raised haemagglutination titres, and there was fairly good agreement between the results obtained with the two methods.

Before the workers were examined at the hospital, respirators had been used for some time, and no serious reactions had occurred during the weeks
Table 4 Antibodies against water soluble extract of $M$ methanolica in sera from unexposed subjects (control sera)

\begin{tabular}{lcc}
\hline & $\begin{array}{l}\operatorname{lgM}(\text { absorbance) } \\
(n=9)\end{array}$ & $\begin{array}{l}\lg G \text { (absorbance) } \\
(n=16)\end{array}$ \\
\hline Range & $34-314$ & $61-349$ \\
Mean \pm SD & $150 \pm 86$ & $130 \pm 73$ \\
\hline
\end{tabular}

Table 5 Levels of $C_{3}$ and $C_{4}$ in serum in two patients after slight exposure to SCP dust

\begin{tabular}{llll}
\hline Patient & $\begin{array}{l}\text { Day afier acute } \\
\text { reaction }\end{array}$ & $C_{3} \mathrm{~g} / \mathrm{l}$ & $\mathrm{C}_{\mathbf{4}} \mathrm{g} / \mathrm{l}$ \\
\hline 1 & 1 & 0.54 & 0.22 \\
& 2 & 0.60 & 0.25 \\
2 & 4 & 0.72 & 0.25 \\
2 & 0.58 & 0.29 \\
Normal value in & 1 & $0.55-1.20$ & $0.20-0.50$ \\
the laboratory & & \\
\hline
\end{tabular}

preceding the examination. Two workers, however, were examined on the day after a slight acute reaction. They had entered the spray-drying room without respirators, and they possibly had a slight fever reaction in the evening and felt tired. The symptoms had disappeared at the examination. The blood was analysed for $\mathrm{C}_{3}$ and $\mathrm{C}_{4}$ complement factors to see if complement activation had occurred (table 5). Both had somewhat low $\mathrm{C}_{3}$ values in the morning after the attack. It was possible to check one of them for four days and during this period the $\mathrm{C}_{3}$ increased significantly while the $\mathrm{C}_{4}$ did not change during the same period.

\section{Discussion}

Untoward reactions against SCP have been described. ${ }^{13}$ The symptoms (asthma and rhinitis) were thought to be mediated by allergy of the immediate type.

The observation that respirators prevented the acute reactions indicates that they were elicited by dust exposure. The aetiology could hardly be infectious because the microorganism is methanol

Table 3 Antibodies against water soluble extract of $M$ methanolica in sera from exposed people at first examination (specimen 1) and about two to three months later (specimen 2)

\begin{tabular}{|c|c|c|c|c|c|c|c|}
\hline \multirow[t]{2}{*}{ Patient } & \multirow[t]{2}{*}{$\begin{array}{l}\text { No of disease } \\
\text { attacks }\end{array}$} & \multicolumn{2}{|c|}{ IgM (absorbance) } & \multicolumn{2}{|c|}{ IgG (absorbance) } & \multicolumn{2}{|c|}{$\begin{array}{l}\text { Passive haemaglutination } \\
\text { (reciprocals of dilution) }\end{array}$} \\
\hline & & Specimen 1 & Specimen 2 & Specimen 1 & Specimen 2 & Specimen 1 & Specimen 2 \\
\hline $\begin{array}{l}1 \\
2 \\
3 \\
4 \\
5 \\
6 \\
7 \\
8\end{array}$ & $\begin{array}{l}5-10 \\
3-4 \\
3 \\
2-3 \\
2 \\
1-2 \\
1 \\
-\end{array}$ & $\begin{array}{r}950 \\
760 \\
2500 \\
25 \\
346 \\
205 \\
1025 \\
160\end{array}$ & $\begin{array}{r}586 \\
3700 \\
342 \\
332 \\
364 \\
3800 \\
170\end{array}$ & $\begin{array}{r}444 \\
1400 \\
879 \\
95 \\
539 \\
422 \\
162 \\
278\end{array}$ & $\begin{array}{r}837 \\
-8000 \\
115 \\
4000 \\
17 \\
12000 \\
400\end{array}$ & $\begin{array}{r}256 \\
>1024 \\
>1024 \\
<8 \\
256 \\
<8 \\
>1024 \\
<8\end{array}$ & $\begin{array}{r}128 \\
-\quad \\
>1024 \\
<8 \\
>1024 \\
256 \\
>1024 \\
-\quad\end{array}$ \\
\hline
\end{tabular}


dependent and cannot be considered as pathogenic to man. Theoretically, however, the pathogenic mechanism could be of an immunological or nonimmunological type.

Type III immune reactions ${ }^{14}$ can occur after repeated exposure to inhaled antigens. The antibodies responsible for these reactions belong to the IgG and IgM classes. Type III-reactions typically occur several hours after exposure to the specific antigen, and are connected with complement activation along the "classical pathway." This is the mechanism behind extrinsic allergic alveolitis, for example.

The patients described here had raised titres of circulating antibodies against a water extract of the microorganisms. This does not necessarily indicate, however, that the acute symptoms were due to antigen-antibody reactions, because exposure to airborne organic dust often results in raised titres of antibodies against dust components even though no symptoms are elicited. This was also observed in one of our patients.

Certain microorganisms, especially Gramnegative bacteria, produce pyrogenic endotoxins, and endotoxin fever has also been described in occupational settings-for example, sewage purification plants ${ }^{15}$ and greenhouses. ${ }^{16}$ Inhalation of endotoxins is considered to result in activation of complement along the "alternate pathway," when $\mathrm{C}_{3}$ and later acting components of the complement system are consumed, while the early acting complement components, including $\mathrm{C}_{4}$, are not affected. ${ }^{17}$

The following observations support the theory of endotoxin fever as the aetiological mechanism. Allergic reactions usually occur only in a low percentage of exposed people, but here, seven of the eight workers fell ill on one or more occasions. The observation that $\mathrm{C}_{4}$ did not change after an attack combined with the indication of $\mathrm{C}_{3}$ consumption might also suggest activation along the "alternate pathway," as in reactions caused by endotoxins. Two subjects developed rhinitis and conjunctivitis at their first known exposure to the SCP.

Irrespective of the pathogenic mechanism, how-ever, it must be considered important to keep airborne dust levels under strict control in the SCP plants. The airborne dust content in the spray drier room was only about $1-4 \mathrm{mg} / \mathrm{m}^{3}$ when the drier was in operation, indicating the high aggressiveness of the dust. Experiences from the use of subtilisin, a protease-active protein, in the detergent industry indicate that granulation of the protein powder could effectively decrease the health risks for exposed workers because the protein could be handled as granules with minimal dust generation. ${ }^{18}$ In the fermentation plant the technique for drying was changed. A more efficient dewatering method was developed, using a flocculation/flotation procedure, and later the conventional spray drier with the rotating atomiser was exchanged and a drying tower with stationary nozzles was used for drying the flocculated suspension. This resulted in a dried end product mainly containing large, non-respirable particles. In this way the risk connected to handling the final product is reduced. This must be considered important, since SCP is used as a protein supplement in animal breeding and, consequently, is handled in many occupational settings where dust control is inadequate.

\section{References}

${ }^{1}$ Brown LR. World food problems. In: Mateles RI, Tannenbaum SR, eds. Single cell protein. Cambridge, Mass: MIT Press, 1968;11-26.

${ }^{2}$ Abbot JC. Economics of single cell protein in relation to world protein supplies. In: Davis P, ed. Single cell protein. Proceeding of the International Symposium, Rome, 7-9 November 1973. London: Academic Press 1974;25-45.

${ }^{3}$ Humphrey AE. Product outlook and technical feasibility of SCP. In: Tannenbaum SR, Wang DIC, eds. Single cell protein II. Cambridge, Mass; MIT Press, 1975;1-23.

4 Hamer G, Harrison DEF. Single cell protein: the technology, economics and future potential. In: Harrison DEF, Higgins IJ, Watkinson R, eds. Hydrocarbons in biotechnology. London: Institute of Petroleum, 1980, 59-73.

${ }^{5}$ Barlet A, Holve WA, Meriel J. Single cell proteins: status and evaluation. Food Engineering International 1978;11:45-8.

- Carter CB. Is biotechnology feeding the Russians? New Scientist 198123 April: $216-8$.

${ }^{7}$ Dostálek M, Häggström L, Molin N. Optimization of biomass production from methanol. Proceedings of the IV IFS: Fermentation Technology. Today 1972;497-501.

8 Undén $\AA$. Computer-aided growth studies in a fermentation process. Stockholm: Royal Institute of Technology, 1977;65-6.

9 Ebbinghaus L, Ericsson M, Lindblom M. Single cell protein production from methanol by bacteria. In: Moo-Young M, Robinson CW, eds. Advances in biotechnology. Vol II. 1981, 413-8.

${ }^{10}$ Voller A, Bidwell DE, Bartlett A. Enzyme immunoassays in diagnostic medicine. Bull WHO 1976;53:55-65.

"' Wasserman J, von Stedingk LV, Biberfeldt G, Petrini B, Blomgren $\mathrm{H}$, Baral $\mathrm{E}$. The effect of irradiation on T-cell suppression of ELISA-determined Ig production by human blood B-cells in vitro. Clin Exp Immunol 1979;38:366-9.

${ }^{12}$ Boyden SV. The adsorption of proteins on erythrocytes treated with tannic acid and subsequent hemagglutination by antiprotein sera. J Exp Med 1951;93:107-20.

${ }^{13}$ Nordman $H$, Keskinen $H$. Luftvägsallergi i en foderjästfabrik och dess omgivning. Proceedings of the 28th Nordic Conference on Occupational Hygiene. Arbetarskyddsstyrelsen, Sverige: 1979,p2:27-8.

${ }^{14}$ Gell PG, Coombs RRA. Clinical aspects of immunology. Oxford: Blackwell Scientific Publications, 1963.

is Mattsby I, Rylander R. Clinical and immunological findings in workers exposed to sewage dust. JOM 1978;20:690-2.

16 Rylander R. Endotoxinfeber i växthus. Läkartidningen 1980;77:1007-8.

${ }^{17}$ Götze O, Müller-Eberhard $\mathrm{HJ}$. The $\mathrm{C}_{3}$ activator system: an alternate pathway of complement activation. J Exp Med 1971;134:90-108.

${ }^{18}$ Göthe CJ, Nilzén $\AA$, Holmgren A, Szamosi A, Werner M, Wide L. Medical problems in the detergent industry caused by proteolytic enzymes from Bacillus subtilis. Acta Allergologica 1972;27:63-86. 